The University of San Francisco

USF Scholarship: a digital repository @ Gleeson Library |

Geschke Center

Philosophy

College of Arts and Sciences

2008

\title{
Racism and the Political Romance of the Browning of America
}

Ronald Sundstrom

rrsundstrom@usfca.edu

Follow this and additional works at: http://repository.usfca.edu/phil

Part of the Ethics and Political Philosophy Commons, Feminist Philosophy Commons, Lesbian, Gay, Bisexual, and Transgender Studies Commons, and the Race, Ethnicity and Post-Colonial Studies Commons

\section{Recommended Citation}

Sundstrom, Ronald, "Racism and the Political Romance of the Browning of America" (2008). Philosophy. Paper 47.

http://repository.usfca.edu/phil/47

This Article is brought to you for free and open access by the College of Arts and Sciences at USF Scholarship: a digital repository @ Gleeson Library | Geschke Center. It has been accepted for inclusion in Philosophy by an authorized administrator of USF Scholarship: a digital repository @ Gleeson

Library | Geschke Center. For more information, please contact repository@usfca.edu. 


\section{Thirty-Four}

\section{RACISM AND THE POLITICAL ROMANCE OF THE BROWNING OF AMERICA}

\section{Ronald R. Sundstrom}

The browning of America promises the bodily, social, and political transformation of the United States, and as with all ethno-racial threats - or promises of deliverance-browning operates through the private, intimate arenas of love, sexuality, gender, family, and friendship. As a demographic idea, the "browning of America" gathers together Native Americans, African Americans, Latinos, Asian Americans, and Americans with a multiracial identity, as well as non-white immigrants. In popular culture, however, it primarily connotes the expanding population of Latinos, and Mexican and Latin American immigrants. Secondarily, it includes the growing social and political presence of multiracial Americans, those who claim more than one racial background, and the growth of interracial romantic relationships. And occasionally, it also includes the expanding presence of Asian Americans and Asian immigrants.

The "browning of America" is a term that is meant to denote the demographic shift of the United States' population to a so-called majority-minority society. The phrase is dramatic and has many detractors, in part because many of the groups included in the phrase are not simply "brown." The phrase reduces the multifaceted shift in the population to a simple rise in the number of brown folks. Despite these objections, I use the phrase precisely because of its problems and social currency. ${ }^{1}$ The phrase, in a nutshell, captures the shifting racial patterns in the United States and thus the changing face of America. A significant portion of the transformative potential of browning, therefore, is due to the role of interracial intimacy in that process. Of course, interracial intimacy, or to the point, interracial sexuality, has been one of the United States' greatest taboos, as was common in racial states, ${ }^{2}$ and as James Baldwin wrote in his reflection on racism, sexuality, and masculinity, "Freaks and the American Ideal of Manhood," interracial sexuality - in ways connected with homosexuality - touches "our most profound terrors and desires." 3 This is the nature of the threat and promise of browning, and is why Americans view it in terms of either salvation or terror.

This chapter explores that disjunctive vision by thinking through the links between racism and interracial intimacy that are and are not made in contemporary philosophical accounts of racism. It makes three claims. First, with a few exceptions, contemporary philosophical investigations of racism, unfortunately and mistakenly, have largely avoided the topic of interracial intimacy. This is an immense mistake, for those matters are the content of our most intimate and daily experiences with race and racism. ${ }^{4}$ Second, this eva- 
sion is related to popular and facile representations of racial harmony and "mosaic" conceptions of diversity that restrict inter-racial associations and friendship to the public sphere and leave racially defined communities largely untouched. Third, although interracial intimacy results from the undermining of racism, the transformative promise of interracial intimacy is largely rhetorical and romantic.

The first claim is most relevant to the topic of the lesbian, gay, bisexual, and transgender issues, because the evasion of interracial intimacy in the contemporary analytic philosophic literature is indicative of the evasion of gender and sexuality in public and pedagogical discussions of racism, and this evasion generally isolates discussions of racism from other forms of oppression, namely sexism and homophobia. The result of this practice has been the masculinization and heteronormalization of the racism debate in the United States. All the same, the other claims are relevant too, because they connect to recent critical discussions of gay and lesbian assimilation of state-sanctioned, racialized, and bourgeois heterosexual norms. ${ }^{5}$

\section{Racism and Sexism}

Discussions of gender, sexuality, and interracial intimacy have been given little room in philosophical accounts of racism. Theories of racism have largely been concerned with the role of reason in racism, explaining its precise moral failure and harm, and identifying the meaning, or behavioral or cognitive essence, of racism. ${ }^{6}$ Contemporary analytic theorists have continued this unfortunate trajectory. This is regrettable as some of their theories have generally clarified the concept of racism, and, in fine detail, catalogued its varying expressions and effects.

In particular, the account given by Lawrence Blum stands out for its clarity, explanatory power, and influence in public and pedagogical discussions of racism. Blum argues for a doxastic, or belief-based, conception of racism. This is in contrast to the non-doxastic accounts of racism that claim that racism only requires an emotive quality, such as hatred, or requires action. While racism often leads to, or stems from some hatred, a subject can believe a racist proposition, and even act on that belief, without hating the people who are the object of his or her belief. Likewise, an individual need not act on the racist beliefs they hold. According to Blum, there are two cores to racism: inferiorization and antipathy. In short, "inferiorization" involves beliefs that some group is racially inferior or superior, and "antipathy" names a feeling of animosity or disgust about a race, and either is required to call some idea, act, or person racist. Because Blum defends a doxastic account, "antipathy" will ultimately have its roots in some belief; further, there are other significant overlaps between instances of inferiorization and antipathy. Moreover, Blum divides racism into three types: personal, social, and institutional. Instances of these types must be related to one of the cores of racism. ${ }^{7}$ 
A great virtue of Blum's theory is that it opens up space for deliberation and discourse within the forums it is employed. His theory opens up this space because he criticizes the drift of the central meaning of racism, and distinguishes so-called true or real racists and racist acts, beliefs, and so on, from mere racial insensitivity, ignorance, and mistakes. Blum, in short, wants to preserve the moral weight of racism for the truly racist. The concern of his theory with our collective racial anxieties and its careful typology of "racism" work well together, for the provision of a deliberative space allows for reflection on racism, and that cannot constructively occur without first managing the panic of racial anxieties.

However, for a work concerned about racial harmony, opening up deliberative space, and addressing the everyday concerns about racism, it is odd for it to then evade considering the intersection of racism with gender and sexuality. He takes time to discuss a variety of topics from racial jokes to the racial politics of school lunchrooms, but he neglects discussions of gendered experiences of racism, as well as the topics of interracial love, sex, marriage, dating, rape, and so on.

"Sexual racism" should at least be treated as a major topic within discussions of racism, right next to "racial jokes," "color-blindness," and so on. That much is needed to increase the relevance of contemporary discussions of racism in our era of browning. Further, given the central role of gender and sexuality in the history and experience of racism, it is appropriate that sexual racism be considered as one of the core semantic themes of racism. This point relies on Baldwin's insight that the pathology of American racism could not be understood apart from violent and dominative expressions of American masculinity.

There are commonly recognized expressions racial-gender-sexual objectifications that are recognized as racist that are not always involved in one or the other themes. Blum's theory easily includes the case where some $X$ views some $Y$ as sexually available or desirable because that $Y$ belongs to race $R$, yet that $X$ holds that $R$ is either inferior or the appropriate object of antipathy. However, this scenario does not cover all the common cases of racial-gendersexual objectifications.

There are many cases of so-called "jungle fever" or such fevers for Asians, Asian Americans, Latinos, and other groups, and at least some of those cases are driven by stereotypes that go beyond racial insensitivity, ignorance, or other racial ills. In such cases, individuals and groups are objectified and reduced to a utility function, in this case some erotic act or set of acts. For example, $X$ may view $Y$ as sexually desirable because $Y$ belongs to race $R$, and $X$ holds that members of $R$ possess race-specific sexual qualities or $X$ is solely interested in sexual adventure and tourism. Either option reduces $Y$ to a racialsexual-gender object, but neither necessarily involves inferiorization or antipathy. In this scenario, racism is comparable to those types of sexism that reduce women to a set of heteorsexual functions that are to be dominated by men, and those forms of anti-homosexual bias that reduce homosexuality to 
some set of same-sex set acts. What is occurring in these scenarios is that the humanity of the recipients of this sort of treatment has been reduced, and they are seen and treated as specific sorts of sexual objects with narrow functions and horizons of experience. These, if you will, obsessions, tell us something about racism that are not captured by Blum's two themes.

Blum may respond that his view of inferiorization already captures these scenarios. However, while this sort of sexual objectification may be consistent with racist views that typically focus on biological and intellectual inferiority, such connections are not necessary. The remedy is that the analysis of racism be opened up and include considerations of gender, sexuality, and specifically interracial intimacy.

\section{Evading Interracial Intimacy}

Why does the contemporary debate avoid the topic of interracial intimacy? Anti-civil rights conservatives of the pre-civil rights era did not avoid this topic, and their ideological descendents remain committed to denouncing interracial sexuality. Indeed, they recognized inter-racial love and sex as the inevitable and terrifying consequent of social equality.

The answer to this question may be found in the history of progressive movements that reacted to racism. In reaction to the white fear of "miscegenation" abolitionists and activists for full-citizenship for non-whites downplayed the possibility of interracial unions, argued that black, Latino, and Native American liberation was not based on their collective desires for white women, or simply avoided the issue. In general, the consensus on the Left for many decades, from abolitionism through the 1960s, was that the topic was politically untouchable; to discuss the matter would play into the hands of racists. The fragmented movements and organization that can be called the Left in the United States has largely followed suit.

It is necessary to overcome our prudishness and force the discussion of racism to go where angels fear to tread-into the realm of the private. The very goals of theories of racial justice that are encased largely within liberal conceptions of the state and international polity, inevitably lead, as the opponents of racial equality have long asserted, to inter-racial and inter-ethnic amalgamation. Whether it is celebrated or mourned, it is a consequence of liberal social organization that must be faced. Social, legal, political, and economic equality within the framework of liberal individualism leads to individuals exercising their freedom of association across racial, ethnic, linguistic, national, and gender lines, totally affecting their public and private lives.

It is not that this result is so obvious that it does not merit discussion, rather a set of conditions hold that serve to continue the evasion. First, there is a general patriarchical prudishness around interracial sexuality that exists for a variety of social and historical reasons. Second, there is the fear of browning, which reinforces the Left's evasion of the topic. Third, a number of theorists likely hold that we can have both racial "harmony" and the long-term conser- 
conservation of traditional American racial and ethnic groupings (Kymlicka, 1995). ${ }^{8}$ They believe and hope that group members will choose not to freely associate across racial and ethnic bedrooms. In short, there is an assumption of a racial mosaic, with a few blurry edges, in liberal forward-looking conceptions of racial justice.

However, the reality of life within a multiracial democracy threatens that vision. Within a liberal democratic framework, broad-based freedoms and the goal of the conservation of group-based identities are at least in tension, and every group faces the possibility of long-term transformation. Despite this obvious problem, the majority of liberal race theorists, even those interested in multicultural rights and citizenship, go nowhere near discussions of interracial sexuality. Rather, they focus on distributive justice and its components, justice in political, social, legal, and economic spheres. Either these philosophers consider interracial intimacy a non-issue, something that may or may not occur in a free society, or they too assume a mosaic vision of racial and ethnic diversity.

At the base of this avoidance, though, is patriarchy. The straight men that dominate discussions of racial justice willfully ignore the private realm. Thus this prudish evasion of interracial intimacy, gender, and sexuality is not innocent; it is a legacy of patriarchy, and it relegates all discussions of the private - in this case interracial intimacy, gender, and sexuality-to feminists and queer theorists. It favors, to a fault, discussions that focus on so-called public matters. In doing so, it ignores everyday experience where most racism occurs, and where ethical analyses of racism could be of great use.

Beyond these so-called private matters, interracial intimacy is intimately connected with the public matters that are taken up in traditional investigations of racial justice. For example, the two main topics of social justice are liberty and distributive justice, and interracial intimacy is involved with both. Interracial intimate relationships - from causal romances to adoption-are done in the face of racisms at all levels, and go against the grain of racist social mores to limit such liberty. Further, this expression of liberty presents ethical challenges to family and community obligations that are asserted for the sake (in the best instances) of the progress and protection of communities that have been racially oppressed.

Likewise, the connection of interracial intimacy to distributive justice is equally pertinent. Distributive justice involves the just distribution of the benefits and burdens of society; it seeks, among other things, to undermine as much as is reasonably possible, racial patterns of disparity across the basic structure of society. In so far as these disparities are rooted in, and reproduced by, patterns of monoracial family formation, increases in forms of interracial intimacy, including rates of interracial marriage, aids in breaking up these disparities.

The above points about the relevance of interracial intimacy for questions of social justice directly confront a common preference within American 
liberalism for forms of external diversity - diversity between groups - that conserves group identity. Likewise, the role of interracial intimacy in the progress toward social justice converges with the earlier point that liberal values of personal autonomy and individual liberty within liberal democracies constantly produce social pressures and opportunities that challenge, undermine, and threaten the group management of individual sexuality. The upshot is that interracial intimacy calls into question the assumptions of group reproduction and identity conservation that is at the heart of many forward-looking visions of racial justice-insofar as a nation that we are wedded to the mosaic image of diversity behind such visions of justice, browning represents a serious challenge.

In direct opposition to the evasion of interracial intimacy, the debate ought to fully grapple with the implications of interracial intimacy. This means re-valuing and putting nearer toward our visions of social justice appreciations of internal, or intra-group, diversity. ${ }^{9}$ It also means accepting that our aesthetic and political sense of what racial justice looks like is open to transformation. This transformative vision is what browning can and should contribute to the public discourse over racial justice.

\section{Humility and Amalgamation}

As we appreciate the transformative power of browning, we should also remember that it is seen as a threat, and it is threatening to more than just white nationalist racists; it is threatening to those who seek the conservation of a wide-array of racial and ethnic communal identities. Although such transformations may be the cost of life within liberal societies, it does us no good as a society to ignore the pain of communal loss. This issue should be handled with great sensitivity and humility, and in such away that does not diminish the equality of those who seek the conservation of traditional ethnoracial identities, or disparages their values.

There are further reasons for humility. One of the main ones is the tendency to overstate the transformative power of browning and interracial intimacy. The advocates of browning are correct to assert the potential for the exchange of social capital that goes along with interracial intimacy, yet they are spectacularly incorrect to see in interracial love and sex the resolution to the world's racial problems. There is a vanity to seeing interracial, especially heterosexual, marriage as the key to all racial division - this concern is related to criticisms of those views that privilege the achievement of same-sex marriage in visions of gay and lesbian liberation. The fantasies of the peculiar transformative power of interracial as well as homosexual marriages arises out of a larger fantasy that we hold about romance and marriage as fundamentally unifying.

Unfortunately for the new amalgamationists and those who hope that interracial intimacy on its own will bring about the beloved community, the actual history of interracial family formation has been deeply marked and 
manipulated by nationalistic projects of economic and political domination. Interracial intimacy brings us nothing if those intimacies are manipulated by the economic and political ends of a nationalism that manages ethnoracial transformation to conserve and reproduce its hegemony, such as seen in the dynamics of brides taken by war or bought by mail-order. ${ }^{10}$ Ultimately, the amalgamation fantasy is hostile to difference and politics, and finds too easy solutions to inevitable political, moral, and even personal, conflicts in yet another vision of homogenous "blood," family, and nation.

The real challenge of browning for the nation and its individuals, families, and communities is the creation of ethical and just interracial public and private lives. While interracial America must overcome the opposition of white nationalist extremists enamored with the fantasy of America as a majority white and evangelical Christian nation, it must also resist multiracial narcissism of a future messianic totality, the smug resolution that within its light brown face all the conflicts of history are finally, and beautifully resolved. The price of that vanity, of course, will be the continued pursuit of American hegemony over developing nations, and the conservation of race-class disparities without the worry that these divisions have anything to do with race. A brown "America" will still be the United States of America, with all its economic, national, and international projects. Certainly this change will profit many more citizens. But, what difference would a brown United States, still wealthy and powerful, make for poor, dark marginal citizens, for the indigenous, for the alien, or for the citizens of other nations?

\section{Notes}

1. Ronald R. Sundstrom, The Browning of America and the Evasion of Social Justice (Albany: State University of New York Press, 2008).

2. David Theo Goldberg, The Racial State (Malden, Mass.: Blackwell, 2002).

3. James Baldwin, "Freaks and the American Ideal of Manhood," Collected Essays, ed. Toni Morrison (New York: Library of America, 1998), pp. 814-829.

4. Charles W. Mills, "Do Black Men Have a Moral Duty to Marry Black Women?" Journal of Social Philosophy, supplement, 25 (1994), pp. 131-153. Also see: Anita L. Allen, "Interracial Marriage: Folk Ethics in Contemporary Philosophy," Women of Color and Philosophy, ed. Naomi Zack (Malden, Mass.: Blackwell, 2000), pp. 182-205; Ellen K. Feder, Family Bonds: Genealogies of Race and Gender (New York: Oxford University Press, 2007); David Theo Goldberg, Racist Culture: Philosophy and the Politics of Meaning (Cambridge, Mass.: Blackwell, 1993); Naomi Zack, American Mixed Race: The Culture of Microdiversity (Lanham, Md.: Rowman and Littlefield, 1995).

5. Nelson, Hilde Lindemann, ed., Feminism and Families (New York: Routledge, 1997).

6. Kwame Anthony Appiah, "Racisms," Anatomy of Racism, ed. David Theo Goldberg (Minneapolis: University of Minnesota Press, 1990), pp. 3-17. See also: Jorge L. A. Garcia, "The Heart of Racism," Journal of Social Philosophy, 27:1 (1996), pp. 5-45; Lawrence A. Blum, "I'm Not a Racist, But . . .": The Moral Quandary of Race (Ithaca, N.Y.: Cornell University Press, 2002); J. Angelo Corlett, Race, Racism, and Reparations (Ithaca, N.Y.: Cornell University Press, 2003).

7. Blum, "I'm Not a Racist, But ...," pp. 1-32. 
8. Will Kymlicka Multicultural Citizenship (Oxford: Clarendon Press, 1995).

9. Appiah, "Racisms," pp. 3-17.

10. HenryYu, "Tiger Woods Is Not the End of History, Or, Why Sex across the Color Line Won't Save Us All," American Historical Review, 108:5 (2003), pp. 14061414. 